\title{
BAPTISAN ANAK
}

\author{
Klarifikasi Teologis terhadap Kontroversi \\ antara Baptisan atau Penyerahan Anak
}

Ady Putra, S. Th.

\section{A. Introduksi}

$\mathrm{G}$ ereja memberikan respon yang beragam ketika berbicara tentang baptisan anak. Ada yang pro, namun tidak sedikit juga yang kontra. Tentu dengan alasan yang dalam perspektif masing-masing paling alkitabiah. Namun tidak sedikit yang seolah-olah bersikap apatis akan diskusi-diskusi semacam ini.

Kelompok yang kontra menganggap baptisan anak tidak alkitabiah. Oleh karena Alkitab sama sekali tidak membahas tentang baptisan anak. Selain itu, anak-anak juga belum bisa mengaku dan memahami iman kepada Kristus. Oleh karena seperti yang dikatakan oleh Dr. Hovey dalam buku Louis Berkhof, "Hanya orang yang percaya dalam Kristuslah yang boleh menerima baptisan dan hanya mereka yang dapat menunjukkan bukti yang diterima bahwa mereka beriman dalam Kristus saja yang boleh dibaptiskan". 'Sehingga banyak gereja sekarang yang tidak lagi mempraktikkan baptisan anak dan menggantinya dengan penyerahan anak. Setelah anak telah besar dan dapat mengaku percaya kepada Kristus, barulah dia akan menerima sakramen baptisan.

Konsep inilah yang juga diyakini dan dipraktikkan dalam Gereja Baptis. Oleh karena bagi mereka, "Baptisan hanya diberikan kepada orang dewasa yang sudah dapat mengakui imannya secara sadar dan bertanggung jawab... baptisan hanya dilayankan kepada orang dewasa". ${ }^{2}$ Menurut Berkhof, "Orang Baptis menunjukkan Amanat Agung sebagai jawaban mereka sebagaimana yang diungkapkan dalam Markus 16:15,16". 3 Artinya, baptisan dilaksanakan setelah pemberitaan Injil. Kemudian berdasarkan istilah bapto dan baptizomai yang menurut Gereja Baptis menunjuk kepada baptis selam, mengindikasikan penolakan terhadap praktik baptisan anak. ${ }^{4}$

Dalam doktrin Gereja Bethel Indonesia (GBI) mengatakan, "Syarat baptisan adalah percaya bahwa Tuhan Yesus Kristus sebagai Juruselamat dan bertobat serta menaati perintahperintah-Nya. Seorang bayi belum tentu mengerti tentang pertobatan dan iman yang sejati. Karena itu, GBI tidak melakukan baptisan kepada bayi, namun yang dilakukan adalah penyerahan anak (1Sam. 1:27-28; Luk. 2:22). Tuhan Yesus tidak melakukan baptisan kepada

${ }^{1}$ Louis Berkhof, Teologi Sistematika 5: Doktrin Gereja, (Surabaya: Momentum, 2005), hlm.153. Bahkan kelompok Anabaptis mengemukakan pernyataan yang lebih keras dan ekstrim, "Anak-anak tidak mempunyai kedudukan dalam gereja”. (Hlm. 143). Dalam bukunya, R.C. Sproul juga mengemukakan beberapa poin yang menjadi alasan kelompok yang kontra terhadap baptisan anak, sebagai berikut: "(1) seorang bayi tidak mampu untuk menyatakan iman percayanya, maka mereka tidak boleh dibaptiskan, (2) baptisan yang dicatat di Perjanjian Baru tidak membicarakan secara khusus untuk baptisan anak, (3)adanya diskontinuitas antara sunat dengan baptisan”. (Sumber: R.C. Sproul, Kebenaran-Kebenaran Dasar Iman Kristen, (Malang: SAAT, 2008), hlm.299.) Berkhof juga mengemukakan beberapa alasan kelompok yang menolak baptisan anak, yakni: "(1) sunat hanyalah peraturan yang jasmaniah belaka dan peraturan seperti itu akan berlalu..., (2)tidak ada perintah eksplisit bahwa anak-anak harus dibaptis..., (3)tidak ada contoh mengenai baptisan anak dalam Perjanjian Baru". (Hlm. 159-161).

${ }^{2}$ http://id.wikipedia.org/wiki/Gereja_Baptis/05/04/2013//

${ }^{3}$ Berkhof, Teologi Sistematika 5: Doktrin Gereja, hlm. 162.

${ }^{4}$ Baca dalam buku Berkhof, Teologi Sistematika 5:...., hlm. 146-147. 
anak-anak kecil, melainkan memeluk anak-anak itu - meletakkan tangan di atasnya dan memberkati mereka (Mrk. 10:13-16)". 5

Selain itu, mayoritas dari mereka mengatakan bahwa itu dilakukan untuk mengikuti teladan Tuhan Yesus. Seperti pernyataan mereka, "Penyerahan anak dilakukan untuk meneladani Tuhan Yesus, di mana anak-anak berusia 8 hari ke atas hingga 12 tahun, diserahkan kepada Tuhan dalam ibadah raya". ${ }^{6}$

Berdasarkan pro-kontra yang dideskripsikan secara singkat di atas, menunjukkan bahwa memang perlu sebuah klarifikasi teologis yang biblika terhadap kontroversi ini. Apakah baptisan anak memang tidak alkitabiah? Apakah penyerahan anak adalah ajaran yang paling unggul sehingga dapat menggugurkan baptisan anak? Sebagai orang Kristen, manakah yang harus dilakukan? Apakah baptisan atau penyerahan anak? Hal inilah yang coba dijawab oleh tulisan ini.

\section{B. Analisis Masalah}

Sebelum memberikan klarifikasi teologis, maka hal yang harus dilakukan adalah menganalisis masalah yang muncul. Sehingga masalah yang muncul dapat dikenali dan diberikan klarifikasi/solusi yang tepat. Berdasarkan deskripsi di atas, maka disimpulkan ada beberapa hal yang menjadi titik tolak penolakan terhadap baptisan anak dan sebaliknya melakukan penyerahan anak, yakni:

1. Alkitab sama sekali tidak mengajarkan tentang baptisan anak.

2. Anak-anak belum bisa mengaku Iman kepada Kristus, sehingga tidak layak dibaptis.

3. Baptisan hanya dapat dilakukan pada saat setelah terjadi Pemberitaan Injil atau setelah terjadi pertobatan, seperti dalam Amanat Agung.

4. Baptisan yang benar dan dikehendaki oleh Tuhan hanya baptisan selam. Secara tidak langsung menolak baptisan anak yang lebih sering menggunakan baptisan percik.

5. Yesus tidak pernah membaptis anak-anak, apa yang dilakukan oleh Yesus dalam Markus 10:13-16 mendukung praktik penyerahan anak.

6. Yesus sendiri tidak pernah dibaptis pada waktu kecil, sebaliknya dia justru diserahkan. Hal ini mendukung praktik penyerahan anak.

\section{Klarifikasi Teologis}

\section{Dasar Baptisan Anak dalam Alkitab}

Satu hal yang perlu untuk digarisbawahi di sini adalah Alkitab tidak pernah secara eksplisit melarang untuk mempraktikkan baptisan anak. Meskipun juga tidak secara eksplisit menegaskan atau menjelaskan pelaksanaan baptisan anak oleh gereja mula-mula. Akan tetapi satu hal yang pasti bahwa covenant dalam Perjanjian Lama yang ditandai dengan sunat kemudian diperbarui dalam Perjanjian Baru melalui baptisan. Sehingga apabila sunat dilakukan kepada anak yang masih berumur delapan hari, maka seharusnya baptisan juga dilakukan kepada anak yang demikian. Tentu hal ini berbeda ketika berbicara tentang baptisan kepada orang yang bertobat pada saat sudah dewasa.

Anak-anak orang Israel disunat supaya turut dimeteraikan dalam iman perjanjian dari orangtua mereka, demikian juga anak-anak orang Kristen yang dibaptis karena orangtua mereka adalah umat Tuhan.

Dengan demikian pada bagian ini akan dibahas beberapa poin yang Alkitab ajarkan tentang baptisan sebagai sebuah tanda umat perjanjian Allah dalam Perjanjian Baru, sama halnya dengan sunat dalam Perjanjian Lama.

\footnotetext{
${ }^{5}$ M. Ferry H. Kakiay, Teologi GBI, (Jakarta: Kapernaum, 2003), hlm. 68.

${ }^{6}$ http://dbr.gbi-bogor.org/wiki/Penyerahan_anak/06/04/2013//
} 
Pertama, Perjanjian Allah dengan Abraham tentang sunat bukan sekadar bersifat jasmani, akan tetapi juga rohani (spiritual) sama seperti baptisan dalam Perjanjian Baru. Bukankah orang yang kontra terhadap baptisan anak selalu mengatakan bahwa sunat tidak boleh dikatakan memiliki kualitas yang sama dengan baptisan. Oleh karena yang pertama sesuatu yang sifatnya jasmani, sedangkan yang lain bersifat rohani.

Pandangan seperti ini adalah pandangan yang keliru. Seperti yang Berkhof kemukakan, "Sifat spiritual dari perjanjian ini dibuktikan dengan cara di mana janji-janjinya ditafsirkan dalam Perjanjian Baru (Rm. 4:16-18; 2Kor. 6:16-18; Gal. 3:8, 9, 14, 16; Ibr. 8:10; 11:9, 10, 13). Juga kita lihat dari kenyataan bahwa sunat adalah sebuah ritual yang memiliki arti penting bagi spiritual (Ul. 10:16; 30:6; Yer. 4:4; 9:25,26; Kis. 15:1; Rm. 2:26-29; 4:11; Flp. 3:2)". ${ }^{7}$ Hal ini kemudian dipertegas oleh Robert G. Rayburn bahwa, "Pekerjaan Roh Kudus ditampilkan mula-mula dalam bentuk ordinasi sunat, yang melambangkan penyucian daging melalui pekerjaan penyucian oleh Roh Kudus... Tentunya jelas bahwa sunat berkaitan dengan realita rohani.. sunat berbicara tentang penanggalan kedagingan. Penanggalan ini bersifat rohani". ${ }^{8}$ Berdasarkan ayat-ayat di atas dan apa yang dikemukakan oleh Berkhof dan Rayburn maka dapat dipastikan sunat tidak hanya menyangkut hal-hal yang jasmaniah akan tetapi yang lebih penting bahwa sunat melambangkan pekerjaan Roh Kudus yang menyucikan umat Allah.

Kedua, dalam Perjanjian Baru baptisan telah menggantikan sunat. Dapatkah dikatakan bahwa dalam Perjanjian Baru, baptisan telah menggantikan sunat? Sehingga secara langsung menegaskan persetujuan terhadap baptisan anak. Oleh karena sunat dilakukan kepada anakanak. Seperti yang dikemukakan oleh Rayburn, "Tanda ini adalah meterai kebenaran iman yang harus diberikan secara dirinya sendiri. Menolak perintah ini berarti menolak cara Allah! Perintah-Nya kepada Abraham yang begitu khusus". ${ }^{9}$ Hal ini berarti bahwa baptisan anak bukanlah sesuatu hal yang tidak alkitabiah. Mengapa? Karena apabila baptisan telah menggantikan sunat maka seharusnya gereja juga mempraktikkan baptisan anak.

Wayne Grudem pun setuju dengan pendapat yang mensejajarkan antara sunat dengan baptisan. Seperti dalam pernyataannya, "In the New Testament, the outward sign of entrance into the 'covenant community' is baptism. Therefore baptism is the New Testament counterpart to circumcision. It follows that baptism should be administered to all infant children of believing parents... The parallel between circumcision and baptism is seen quite clearly in Colossians 2(2:11-12)". ${ }^{10}$ Bagi Grudem, baptisan adalah lambang untuk masuk ke dalam komunitas covenan. Sama seperti sunat, anak-anak juga dibaptis berdasarkan iman orangtua mereka. Baginya, pemahaman seperti ini sudah dengan jelas dan tegas dikemukakan oleh Paulus dalam Kolose 2:11-12. Hal ini tentu menjawab keraguan banyak pihak yang beranggapan adanya sifat diskontinuitas antara sunat dalam Perjanjian Lama (karena lebih bersifat jasmani) dengan baptisan anak dalam Perjanjian Baru (karena lebih bersifat spiritual).

Jadi dapat dikatakan bahwa sunat tidak lagi berfungsi sebagai lambang dan meterai pentahbisan sebagai umat Allah dalam Perjanjian Baru. Seperti yang dikemukakan dalam Kisah Para Rasul 15:1,2; 21:21; Galatia 2:3-5; 5:2-6; 6:12,13,15.

Ketiga, beberapa peristiwa dalam Alkitab yang menyetujui baptisan anak. Kelompok yang kontra terhadap baptisan anak selalu beranggapan bahwa anak-anak tidak memiliki posisi dalam gereja. Mereka tidaklah diperhitungkan sebagai anggota dalam jemaat Tuhan. Apakah konsep yang demikian benar? Berikut ini beberapa peristiwa dalam Alkitab yang menyetujui baptisan anak.

\footnotetext{
${ }^{7}$ Berkhof, Teologi Sistematika 5..., hlm. 154.

${ }^{8}$ Robert G. Rayburn, Apa Itu Baptisan?, (Surabaya: Momentum, 2009), hlm. 10, 59.

${ }^{9}$ Ibid.,

${ }^{10}$ Wayne Grudem, Systematic Theology: An Introduction To Biblical Doctrine, (Michigan, USA: Grand Rapids, 2011), p. 976.
} 
(C) Dalam Keluaran 12:37, menceritakan peristiwa Musa memimpin orang Israel keluar dari tanah Mesir, yang di dalamnya termasuk anak-anak. Penjelasan Rasul Paulus dalam 1 Korintus 10:2 menegaskan bahwa mereka yang ikut pada saat itu dibaptis dalam awan dan dalam laut - tidak terkecuali anak-anak. Bagi Rayburn, peristiwa ini dapat menunjuk kepada baptisan anak-anak. ${ }^{11}$

(C) Dalam Kisah Para Rasul 16:15, 33, mengisahkan tentang Rasul Paulus pada waktu berada di Filipi. Di sana dia membaptis Lidia serta seisi keluarganya, dan Kepala Penjara serta seisi rumahnya. Kata yang dicetak miring mengindikasikan bahwa di dalamnya juga termasuk anak-anak. Bagi Berkhof, "Sangat mungkin (tetapi tidak terlalu pasti) bahwa tidak satupun dari anggota keluarga itu berisi anak-anak. Dan jika seandainya ada bayi di sana, secara moral pastilah bayi itu juga dibaptiskan bersama orangtuanya." 12

(2) Dalam 1 Korintus 1:16, ketika Rasul Paulus mengatakan bahwa dia pun turut membaptiskan keluarga Stefanus. Hal inipun menyiratkan bahwa ada kemungkinan anakanak yang ada dalam keluarga Stefanus pun turut dibaptiskan.

Dengan demikian, berdasarkan peristiwa-peristiwa di atas mengindikasikan bahwa baptisan anak juga diajarkan oleh Alkitab. Meskipun tidak secara gamblang atau tegas. Akan tetapi dari kisah-kisah di atas mengingatkan orang Kristen bahwa baptisan anak juga sangat mungkin telah dipraktikan pada zaman Tuhan Yesus serta para Rasul.

\section{Arti kata Bapto dan Baptizomai}

Kedua kata ini perlu diberikan penjelasan, oleh karena terkait cara pembaptisan mana yang benar menurut Alkitab. Tidak sedikit orang Kristen menolak baptisan anak oleh karena beranggapan baptisan percik tidak alkitabiah.

Orang Baptis seringkali menerjemahkan kata bapto atau baptizo dengan membaptiskan. Bahkan mereka beranggapan bahwa arti dari kedua kata di atas hanya berarti 'mencelupkan'. Tidak ada arti yang lain lagi. Akan tetapi argumentasi ini kemudian ditolak oleh Carson. Seperti pernyataan Carson ${ }^{13}$ yang dikutip oleh Berkhof bahwa, "Kata itu bisa berarti 'mewarnai', sehingga bisa saja diterjemahkan 'mewarnai dengan cara mencelup' atau bahkan juga berarti 'mewarnai dengan cara apapun'. Akibatnya itu tidak akan menunjuk tentang cara membaptiskan." 14

Akan tetapi kembali muncul pertanyaan, "Apakah kata baptizo berasal dari kata bapto? Bagi Carson, kata bapto adalah akar kata dari baptizo. Akan tetapi memiliki dua arti yakni, 'mencelup' dan 'mewarnai'. Sedangkan baptizo memiliki satu arti saja, yakni 'mencelup'. Sehingga hal inilah yang kemudian dipegang oleh orang Baptis untuk menyatakan bahwa baptisan dengan cara selamlah yang diperintahkan oleh Tuhan." 15

Apakah pendapat seperti ini dapat diterima? Untuk menjawab apa yang dikemukakan oleh Carson, maka baik sekali untuk mengutip pendapat Wilson. Baginya,

Kata baptizo barangkali tidak sedemikian mengungkapkan tindakan menaruh seseorang berada di bawah air sebagaimana keadaan sesuatu pada kondisi itu, tidak peduli bagaimana bisa terjadi seperti itu, apakah dimasukkan dalam air, atau air itu yang dibawa pada benda tersebut. Walaupun sesungguhnya cara yang paling umum adalah membawa benda itu ke dalam air, tetapi sesungguhnya tidak harus begitu maksudnya...menurut pemakaian bahasa Yunani, baptisan dimungkinkan melalui beberapa cara. ${ }^{16}$

\footnotetext{
${ }^{11}$ Baca: Rayburn, hlm. 55.

12 Berkhof, hlm. 157.

${ }^{13}$ Carson termasuk salah seorang tokoh yang cukup berpengaruh di Gereja Baptis.

${ }^{14}$ Berkhof, hlm. 147.

15 Ibid.,

${ }^{16}$ Ibid., hlm. 148.
} 
Pandangan Wilson memiliki perbedaan yang sangat signifikan dengan pandangan Carson. Wilson tidak menyangkal bahwa memang arti kata baptizo adalah mencelupkan. Akan tetapi bukan berarti hanya melalui satu cara saja, yakni membawa benda itu ke dalam air. Bagi Wilson, meskipun itu cara yang paling umum digunakan apabila dikaitkan dengan kata ini, namun tidak menutup kemungkinan dapat dilakukan dalam beberapa cara. Sama halnya dengan baptisan. Jadi yang mau ditekankan di sini bahwa baptizo memiliki arti memandikan atau membasuh, mau dengan cara selam atau percik itu tidak menjadi soal.

James Montgomery Boice menambahkan guna mempertegas pendapat Wilson di atas. Dengan mengutip tulisan dari Nicander (seorang tabib dan penyair dari Yunani), Boice menyatakan, "Sayur seharusnya lebih dahulu dicelupkan (bapto) dalam air yang mendidih dan kemudian dibaptis (baptizo) dalam larutan asam cuka. Keduanya berkaitan dengan membenamkan sayur dalam larutan. Tetapi yang pertama (bapto) adalah sementara, sedangkan yang kedua, tindakan membaptis sayur, menghasilkan perubahan yang permanen." ${ }^{\prime 17}$ Dari apa yang dikemukakan oleh Boice di atas, meskipun lebih mengunggulkan baptisan secara selam, akan tetapi yang perlu digarisbawahi adalah dari kata baptizo sebenarnya lebih pas jika diterjemahkan dalam tindakan yang konkret melalui baptisan percik.

Berkhof sendiri berargumen, "Pemurnian ini dimungkinkan melalui pemercikan, dapat kita lihat dalam Bilangan 8:7; 19:13, 18, 19, 20; Mazmur 51:7; Yehezkiel 36:25; Ibrani 9:10... Juga pengertian mencelup tidak bisa kita terapkan dalam ayat-ayat: Matius 3:11; Lukas 11:37, 38; 12:50; Roma 6:3; 1Korintus 12:13; Ibrani 9:10; 1Korintus 10:1,2. Maka kata baptizo tidak harus berarti 'menyelam'."' 18

Meskipun dalam pembahasan di atas sedikit lebih menonjolkan kelebihan dari baptisan percik, dan sebaliknya lebih memojokkan baptisan selam. Akan tetapi tetap penekanan tulisan ini bukan untuk menghakimi baptisan mana yang benar atau salah. Tulisan ini lebih bersifat klarifikasi. Sehingga apabila merujuk penjelasan di atas, secara tegas dan jelas melegalkan baptisan percik. Yang secara tidak langsung melegalkan baptisan anak. Oleh karena orang Baptis menolak baptisan anak, karena baranggapan baptisan percik tidak alkitabiah.

\section{Kesaksian Bapa-bapa Gereja}

Kesaksian Bapa-bapa gereja adalah bukti di luar Perjanjian Baru yang dapat digunakan untuk mengetahui apakah praktik baptisan anak sudah dilakukan oleh gereja sejak itu ataukah di kemudian hari. Sehingga secara tidak langsung menegaskan praktik baptisan anak merupakan warisan dari para Rasul meskipun Perjanjian Baru tidak dengan tegas menjelaskan praktik itu telah dilakukan oleh para Rasul.

Sebagai catatan, Bapa-bapa Gereja sangat mengaitkan baptisan dengan kelahiran kembali. Mereka seringkali menggunakan istilah 'kelahiran kembali' menunjuk kepada 'baptisan' ${ }^{19}$

Origen. Greg Johnson menjelaskan pendapat Origen bahwa, "Infant baptism was the ancient practice, not only in Origen's own Egypt, but throughout the Christian world since the earliest days". ${ }^{20}$ Jadi, Origen yang lahir dan dibaptis (kemungkinan juga dibaptis kecil) sekitar tahun 180 AD juga begitu yakin akan praktik baptisan anak sudah menjadi tradisi yang selalu dilakukan dalam gereja sejak awal.

Justinus Martir. Dia memberikan testimoni, "Orang tua baik laki-laki dan perempuan dan orang yang berumur 70 tahun telah menjadi murid Kristus sejak saat masa kanak-kanak

\footnotetext{
${ }^{17}$ James Montgomery Boice, Dasar-dasar Iman Kristen, (Surabaya: Momentum, 2011), hlm. 692.

18 Berkhof, hlm. 148-149.

${ }^{19}$ Berkhof, hlm. 158.

${ }^{20}$ Greg Johnson, Article:Infant Baptism, p. 4.
} 
mereka". ${ }^{21}$ Artinya, seseorang dikatakan murid Kristus bukan hanya pada saat dia telah dewasa. Akan tetapi identitas itu dipakainya sejak bayi. Sehingga seseorang yang lahir dalam keluarga yang telah menjadi Kristen, baiknya diberikan tanda yang akan menunjukkan identitasnya melalui baptisan. Sehingga dapat dikatakan bahwa apa yang dikatakan oleh Martir di atas mengindikasikan persetujuannya terhadap baptisan anak.

Irenaeus. Dia berkata, "Ia (Yesus) datang untuk menyelamatkan manusia melalui diriNya sendiri. Mereka yang diselamatkan melalui Dia dilahirbarukan kepada Allah, baik bayi maupun anak kecil, anak-anak yang sudah agak besar, para pemuda dan orang-orang tua". ${ }^{22}$ Meskipun tidak secara eksplisit menjelaskan tentang baptisan anak, namun dapat dianggap sebagai sebuah rujukan terhadap pengakuan akan praktik baptisan anak. Karena seperti yang sudah dijelaskan di atas bahwa Bapa-bapa Gereja selalu mengaitkan baptisan dengan kelahiran kembali.

Tertulianus. Dia adalah satu-satunya tokoh dari golongan Bapa-bapa Gereja yang menyarankan supaya baptisan tidak dilakukan kepada anak-anak - sebaiknya ditunda. Meskipun dari banyak tulisannya menunjukkan bahwa pada paruh kedua abad kedua, baptisan anak telah biasa dilakukan dalam gereja.

Hippolytus. Dia berpendapat bahwa, "Dan pertama-tama baptislah anak-anak kecil; dan apabila mereka dapat berbicara, mereka sebaiknya dibaptis, tetapi apabila tidak, orangtua atau walinya yang berbicara atas nama mereka". ${ }^{23}$ Sekali lagi, bahwa dalam pandangan Hippolytus mengindikasikan tentang praktik baptisan anak yang telah dilakukan dalam gereja perdana.

Berdasarkan kesaksian dari Bapa-bapa Gereja di atas menunjukkan bahwa dalam sejarah gereja perdana tidak terdapat larangan untuk membaptis seseorang berdasarkan umur. Justru sebaliknya, di mana menunjukkan bahwa dalam gereja perdana telah dipraktikkan baptisan dewasa dan juga baptisan anak. Bahkan nyaris tidak ada dari Bapa-bapa Gereja yang menyangkal atau mempertanyakan validitas baptisan anak.

\section{Makna Baptisan Anak}

Kelompok yang kontra terhadap baptisan anak selalu berangkat dari anggapan bahwa karena anak belum bisa mengaku imannya, sehingga mereka tidak layak untuk dibaptiskan. Selain itu mereka juga selalu berdalih bahwa baptisan sebaiknya dilakukan setelah pemberitaan Injil. Jadi, bagi mereka baptisan anak adalah baptisan yang salah. Berdasarkan hal di atas maka perlu untuk melihat kembali, apa sebenarnya makna dari baptisan anak? Berikut ini akan diuraikan beberapa makna dari baptisan anak.

Baptisan anak adalah lambang dari Perjanjian Anugerah. Karl Barth mengatakan, "Baptisan Kristen pada hakikatnya merupakan lambang (abbild) dari pembaruan seseorang di dalam kematian dan kebangkitan Yesus Kristus, sehingga dengan demikian melambangkan hubungannya dengan Kristus, yaitu dengan perjanjian anugerah yang diadakan dan digenapi di dalam Dia, dan dalam persekutuan dengan Gereja-Nya". ${ }^{24}$ Hal itu berarti bahwa anak-anak pun harus dibaptis, oleh mereka juga memiliki dosa warisan yang tentu membutuhkan kematian dan kebangkitan Yesus. Meskipun itu sekadar lambang saja. Selain itu, mereka juga adalah murid Kristus walaupun mereka sendiri belum bisa bersaksi untuk hal itu dengan mulut mereka. Tetapi justru melalui baptisan, mereka dapat bersaksi kepada dunia tentang iman yang mereka miliki. Oleh karena seperti yang dikemukakan oleh John Calvin bahwa, "Baptisan sebagai tanda permulaan di mana kita diterima ke dalam masyarakat gereja, agar dicangkokkan dalam Kristus, kita dapat diperhitungkan di antara anak-anak Allah. Permulaan

\footnotetext{
${ }^{21} \mathrm{http} / /$ : ourunity.blogspot.com/2007/10/baptisan-bayi-sebuah-tinjauan.html/05/04/2013//

22 Berkhof, hlm. 158.

${ }^{23} \mathrm{http} / /$ : ourunity.blogspot.com/2007/10/baptisan-bayi-sebuah-tinjauan.html/05/04/2013//

${ }^{24}$ Millard J. Erickson, Teologi Kristen Volume Tiga, (Malang: Gandum Mas, 2004), hlm. 387.
} 
itu memiliki dua tujuan: pertama, menyampaikan iman kita di hadapan Dia; kedua, menyampaikan pengakuan kita di hadapan manusia". ${ }^{25}$

Pendapat yang mengatakan bahwa anak-anak belum bisa dikategorikan sebagai anggota gereja adalah pendapat yang sangat keliru. Oleh karena dalam Perjanjian Lama menunjukkan bahwa Tuhan selalu mengikutsertakan anak-anak dalam perjanjian-Nya dengan umat Israel. Hal itu berarti anak-anak juga adalah umat Allah. Dan yang menjadi lambangnya bagi mereka adalah mereka disunat (bnd. Kej. 17:9-14). Sunat menjadi kesaksian dari anak-anak Israel kepada dunia bahwa mereka adalah umat Tuhan, sekaligus menjadi lambang iman di hadapan Tuhan.

Dengan demikian, baptisan anak juga berfungsi sebagai lambang kesaksian anak-anak orang Kristen di dalam zaman Perjanjian Baru kepada dunia bahwa mereka adalah umat Tuhan. Sekaligus menjadi lambang iman di hadapan Kristus. Bagi Erickson, "Baptisan merupakan pengungkapan kebenaran mengenai apa yang telah dilakukan Kristus; baptisan merupakan 'firman dalam air' yang bersaksi tentang keterlibatan dan keikutsertaan orang percaya di dalam kematian dan kebangkitan Kristus (Rom. 6:3-5)."26 Jadi, anak-anak orang Kristen sejak balita harus dipersatukan dengan Kristus di dalam kematian dan kebangkitanNya. Hal inilah yang Rasul Paulus sebutkan sebagai sunat Kristus dalam Kolose 2:11. Oleh karena dasar dari setiap orangtua mendidik anak-anaknya adalah baptisan. Setelah dibaptis, anak-anak kemudian dididik oleh orangtua untuk dapat hidup seperti yang dikehendaki oleh Kristus.

Inilah yang dimaksudkan dari baptisan anak adalah lambang dari Perjanjian Anugerah, di mana melaluinya anak-anak orang Kristen dipersatukan atau dicangkokkan ke dalam kematian dan kebangkitan Yesus Kristus. Hal ini paralel dengan sunat dalam Perjanjian Lama sebagai lambang dari covenan Allah dengan bangsa Israel, yang melaluinya anak-anak dari orang Israel dipersatukan atau dimasukkan ke dalam covenan tersebut.

Baptisan anak sebagai alat anugerah bagi anak dan orangtua. Menurut teologi Reformed seperti yang dikemukakan oleh Berkhof, "Baptisan adalah sebuah sarana untuk menanamkan anugerah dalam bentuk yang spesifik dari kelahiran kembali kita dan kita disatukan dalam Kristus". ${ }^{27}$ Pandangan ini merupakan klaim yang menolak anggapan Reformed sebelumnya yang menganggap baptisan hanya sekadar untuk menguatkan suatu syarat anugerah.

Luther sendiri bergumul tentang persoalan ini. Awalnya dia menganggap bahwa kebaikan baptisan itu tergantung pada iman si penerimanya. Kemudian ketika Luther menyadari bahwa ternyata anak-anak tidak dapat menunjukkan iman mereka, maka dia cenderung untuk meyakini bahwa Tuhan melalui anugerah mengikatkan iman pada mereka pada baptisan. Tentu pandangan Luther ini bukanlah solusi terhadap pokok diskusi ini.

Akan tetapi kemudian beberapa teolog Reformed memberikan solusi guna menyelesaikan masalah ini, seperti yang dijelaskan oleh Berkhof berikut ini,

(1)Mungkin saja untuk tetap berasumsi bahwa anak-anak yang dibawa untuk dibaptiskan, dilahirkan kembali dan dengan demikian memiliki semen fidei (benih iman); dan berpegang bahwa Tuhan melalui baptisan dengan suatu cara yang mistis, yang tidak kita pahami, menguatkan benih iman ini dalam anak-anak; (2)...bahwa tindakan baptisan sebagai alat anugerah tidak harus dibatasi pada peristiwa saat baptisan itu dilaksanakan, lebih daripada pelaksanaan Perjamuan Kudus yang terbatas pada waktu perayaan itu diadakan. Pada saat baptisan dilaksanakan terjadi sesuatu yang sangat misterius untuk meningkatkan anugerah Allah dalam hati, tetapi bisa juga menjadi alat untuk menambahkan iman pada waktu kemudian, ketika arti penting baptisan sudah di

${ }^{25}$ David W. Hall, Peter A. Lillback (Editor), Penuntun Ke Dalam Teologi Intitutes Calvin, (Surabaya: Momentum, 2009), hlm. 430.

${ }^{26}$ Erickson, hlm. 387-8.

${ }^{27}$ Berkhof, hlm. 170. 
mengerti...(3)..Baptisan anak juga alat anugerah bagi orangtua yang membawa anaknya untuk dibaptiskan. Baptisan itu menguatkan iman pada janji-janji Tuhan, mengerjakan dalam diri mereka jaminan bahwa anak-anak mempunyai hak untuk memiliki perjanjian anugerah, dan menguatkan rasa tanggung jawab dalam diri para orangtua untuk pendidikan Kristen bagi anak-anak mereka. ${ }^{28}$

Berdasarkan penjelasan beberapa teolog Reformed yang dikutip oleh Berkhof, maka menjadi jelas bahwa baptisan sebagai alat anugerah dapat memberikan tiga efek yang sangat signifikan kepada anak. Sehingga apabila seorang anak yang dilahirkan dalam keluarga Kristen namun tidak dibaptis, maka akan merugikan anak itu sendiri. Oleh karena: (1) melalui baptisan, Allah dapat bekerja secara mistis untuk menguatkan iman anak, (2) setelah dibaptis, maka Allah akan bekerja secara misterius dan progresif guna meningkatkan anugerah Allah dalam hati anak yang kelak mencapai titik klimaksnya ketika anak sudah memahami arti baptisan tersebut, dan (3) melalui baptisan, maka orangtua juga merasakan sebuah keyakinan akan janji Allah yang telah diterima oleh anak-anak mereka - membuat orangtua bertanggungjawab dalam mendidik anak seturut dengan kehendak Tuhan.

Baptisan anak sebagai titik awal untuk membangun iman. Apakah anak-anak telah memiliki iman? Pasti sulit untuk mengatakan bahwa anak-anak belum memiliki iman. Yang menjadi persoalan adalah mereka belum menyadari akan iman mereka. Sehingga mereka masih memerlukan didikan dari orangtua guna secara progresif mengantar mereka kepada kesadaran akan iman dalam diri mereka. Kalau memang benar demikian, maka sangatlah keliru jikalau orang Kristen tidak membaptiskan anaknya hanya dengan alasan bahwa mereka belum memiliki iman.

Bagi Calvin, "Baptisan membangun iman dalam diri orang Kristen dan dalam gereja..."29 Hal yang hampir sama dikemukakan oleh Harun Hadiwijono, "Baptisan tanpa iman tidaklah mungkin, akan tetapi sebaliknya, iman tanpa baptisan juga tidak mungkin". ${ }^{30}$ Kedua pendapat di atas ingin menegaskan bahwa apabila selama ini baptisan anak sudah dilaksanakan oleh gereja sejak gereja mula-mula maka tentu mereka sudah meyakini bahwa anak-anak juga telah memiliki iman. Ada kemungkinan para Rasul juga mengajarkan demikian, oleh karena mayoritas Bapa-bapa Gereja mengajarkan dan mempraktikkan baptisan anak - di mana ajaran Bapa-bapa Gereja masih sangat dekat kepada ajaran para Rasul.

Bahkan Calvin berpikir sedikit lebih maju, dengan pendapatnya bahwa baptisan dapat membangun iman. Karena bagi Calvin melalui baptisan mendatangkan tiga hal, yakni:

Janji pertama adalah penyucian, atau pengampunan dosa..Baptisan meyakinkan orang Kristen bahwa janji pengampunan yang diberikan dalam Injil adalah benar dan dapat dipercaya. Janji yang kedua dari baptisan adalah untuk mematikan daging dan pembaruan... Allah berjanji untuk membenarkan umat-Nya juga berjanji dalam baptisan untuk menguduskan mereka secara progresif baik dalam mematikan kehidupan daging maupun dalam memperlihatkan kehidupan oleh Roh. Jaminan yang ketiga dari baptisan adalah bahwa kita disatukan dengan Kristus sendiri sehingga kita mengambil bagian dalam semua berkat-Nya. Baptisan adalah ikatan persatuan dan persekutuan yang paling teguh di mana Ia telah berkenan untuk membentuk kita. Orang-orang Kristen disatukan dengan Kristus sebagai Kepala mereka sehingga semua manfaat dari pekerjaan-Nya adalah milik mereka. ${ }^{31}$

\footnotetext{
${ }^{28}$ Ibid., hlm. 170-1

${ }^{29}$ Hall, dan Lillback, hlm. 430.

${ }^{30}$ Harun Hadiwijono, Iman Kristen, (Jakarta: BPK Gunung Mulia, 2005), hlm. 450. (Cetakan ke-16)

${ }^{31}$ Hall, dan Lillback, hlm. 430-1.
} 
Ketiga jaminan di atas yang Calvin maksud dapat membangun iman dalam diri setiap orang Kristen termasuk anak-anak. Artinya, iman yang telah mereka miliki sebelumnya dapat dibangun melalui baptisan. Dibangun dalam pengertian bahwa mereka akan mengalami perubahan secara progresif. Sekali lagi pemahaman ini menunjukkan bahwa baptisan penting dan wajib dilakukan kepada anak-anak.

Hadiwijono mengatakan, "Karena baptisannya anak-anak itu harus ditandai oleh ketaatan di dalam iman. Memang harus diakui, bahwa yang menghubungkan anak itu dengan baptisannya bukan imannya sendiri, melainkan iman orangtuanya. Karena iman orangtuanya maka anak-anak dihubungkan dengan perjanjian Allah dan dengan tanda perjanjian-Nya. Para anak ditanamkan kepada Kristus, karena orangtuanya ditanamkan kepada Kristus". ${ }^{32}$ Melalui baptisan, anak-anak orang Kristen akan betumbuh dalam iman. Atau baptisan akan membangun iman dalam diri setiap anak. Karena baptisanlah yang melambangkan bahwa seorang anak telah ditanamkan kepada Kristus. Ibarat tumbuhan yang tidak akan bisa bertumbuh apabila tidak ditanam ke dalam tanah. Begitu pula iman apabila tidak ditanam ke dalam Kristus maka tidak akan mengalami pertumbuhan. Jadi, baptisan akan membangun iman anak-anak dalam tiga janji seperti yang telah dikemukakan oleh Calvin di atas.

Berdasarkan penjelasan di atas, maka dapat dilihat dengan jelas ada perbedaan antara baptisan yang dilakukan terhadap anak-anak dengan yang dilakukan terhadap orang dewasa. Atau juga terdapat perbedaan yang signifikan antara baptisan anak dengan baptisan yang dilakukan setelah pemberitaan Injil. Oleh karena baptisan anak dilakukan lebih kepada aspek perjanjian. Sehingga setiap anak yang dibaptis itu berdasarkan iman orangtua. Meskipun juga tidak dapat disangkal bahwa ternyata anak kecil telah memiliki iman yang bagi mereka sendiri belum tentu menyadarinya. Justru karena itulah, maka iman mereka harus dimeteraikan melalui baptisan supaya dapat secara progresif dalam pemeliharaan Allah Tritunggal mengalami perkembangan.

\section{Evaluasi terhadap Praktik Penyerahan Anak}

Dasar Alkitab bagi praktik penyerahan anak adalah, "Anak-anak Israel pada waktu lahir, bagi bayi laki-laki ia harus disunat pada umur 8 hari dan diberi nama (Im.12:1-3; Luk. 2:21). Sesudah anak-anak berumur 33 hari, maka mereka harus dibawa ke Rumah Tuhan untuk diserahkan kepada Tuhan. Orangtuanya harus membawa korban bakaran dan korban penghapus dosa berupa seekor anak domba atau dua ekor burung tekukur atau dua ekor anak burung merpati (Im. 12:1-8; Lukas 2:22-24). Banyak anak-anak kecil dibawa oleh orangtuanya kepada Tuhan Yesus, dengan maksud agar Dia memberkati anak-anak (Mat. 19:13-15; Mrk.10:13-16; Luk. 18:15-17)". ${ }^{33}$

Meskipun ada juga gereja yang mempraktikkan penyerahan anak dengan mendasarinya hanya kepada Matius 19:13-15; Markus 10:13-16; Lukas 18:15-17. ${ }^{34}$

Berdasarkan ayat-ayat inilah mereka melakukan penyerahan anak sekaligus menolak praktik baptisan anak. Bahkan lebih ekstrim lagi mereka berkata bahwa praktik baptisan anak sangat tidak alkitabiah. Benarkah demikian?

Tulisan ini tidak bermaksud untuk menghakimi, melainkan untuk memberikan klarifikasi guna meluruskan setiap pandangan yang keliru. Dengan demikian, perlu dilihat ayat-ayat tersebut satu per satu. Di mulai dari Imamat 12:1-8; Matius 19:13-15; Markus 10:13-16; dan Lukas $2: 21 ; 18: 15-17$.

Imamat 12:1-8. Dalam pasal ini sama sekali tidak menyinggung sedikitpun tentang penyerahan anak. Kalau memang ayat 3 adalah maksud kelompok ini justru itu adalah kekeliruan yang besar. Oleh karena ayat itu justru berbicara tentang sunat. Di mana apabila

\footnotetext{
${ }^{32}$ Hadiwijono, hlm. 452.

${ }^{33} \mathrm{http}: / / w w w . g b i w t c s e r p o n g . o r g / i n d e x . p h p / f o r m u l i r-p e n y e r a h a n-a n a k-2 / 27 / 04 / 2013 / /$

${ }^{34}$ http://dbr.gbi-bogor.org/wiki/Penyerahan_anak/06/04/2013//
} 
membaca surat-surat Paulus (seperti dalam Kol. 2:11-13), justru mengaitkan sunat dengan baptisan (anak). Seperti yang dikemukakan oleh Charles C. Ryrie, "Kolose 2:11,12 dengan jelas menghubungkan sunat dengan baptisan. Karena menurut Perjanjian Lama setiap bayi disunat, maka menurut Perjanjian Baru mereka harus dibaptiskan". ${ }^{35}$

Jadi, apabila berdasarkan ayat ini (Im.12:1-8) maka gereja seharusnya mempraktikkan baptisan anak bukan penyerahan anak. Karena elaborasi biblika yang Paulus kerjakan dengan bantuan dari Roh Kudus justru mengaitkan ayat ini dengan baptisan anak, bukan penyerahan anak.

Matius 19:13-15; Markus 10:13-16; Lukas 18:15-17. Perikop-perikop ini bercerita tentang anak-anak kecil datang kepada Yesus, dan kemudian Yesus meletakkan tangan-Nya dan mendoakan mereka. Memang ayat ini yang selalu menjadi ayat kunci bagi gereja penganut penyerahan anak. Akan tetapi, benarkah perikop-perikop ini berbicara tentang praktik penyerahan anak?

Menurut R. T. France untuk perikop dalam Matius 19:13-15, "It was custom to bring a child to the elders on the evening of the Day of Atonement to bless him and pray for him". ${ }^{36}$ Sedangkan frasa Lalu Ia metelakkan tangan-Nya atas mereka..”, bagi France, “...It is more generally an act of identification and acceptance, not no mention a naturally affectionate response to children". ${ }^{37}$ Artinya, ayat ini sama sekali tidak berbicara tentang penyerahan anak di dalam Bait Allah atau Sinagoge. Kalau pun memang ada semacam tradisi dalam budaya orang Yahudi untuk membawa anaknya kepada orang yang lebih tua untuk didoakan dan diberkati, akan tetapi pasti anak-anak mereka juga telah disunat. Di mana sunat adalah tindakan yang parallel dengan baptisan anak dalam Gereja.

Menurut R. Alan Cole untuk perikop dalam Markus 10:13-16, "Apart from this, we may see in the anecdote the faith in Jesus shown by the parents who brought their children to Him to touch (verse 13) in blessing (verse 16)... There have been those who see something almost superstitious [superstition to touch the garment of Jesus in hope of healing] in the action of these parents". ${ }^{38}$ Bahkan Cole menambahkannya, "..the indignation of Jesus(14) at this action of His disciples, as showing their utter whole nature of the kingdom, where none is unimportant in God's eyes". ${ }^{39}$ Bagi Cole ada hal yang ditunjukkan orangtua di sini yang bersifat takhyul dalam hal penyembuhan, meskipun ada kemungkinan lain, yakni hanya berbicara tentang iman orangtua. Bahkan bagi Cole dari peristiwa ini justru mengindikasikan bahwa di mata Tuhan semua sama, baik orang dewasa maupun anak-anak. Nah.. bukankah kelompok yang pro terhadap penyerahan anak selalu beranggapan bahwa anak-anak tidak boleh dibaptis karena mereka belum bisa dikategorikan sebagai anggota Gereja (belum bisa mengaku iman percaya kepada Tuhan). Tentu hal tersebut bertolak belakang dengan sikap Yesus dalam perikop ini yang justru menganggap anak-anak sama saja dengan orang dewasa.

Justru informasi yang mencengangkan dari Jacob van Bruggen menegaskan, "Sejak dulu, perikop ini dipakai untuk membenarkan baptisan anak, salah satu tokoh yang menggunakannya adalah Tertulianus". ${ }^{40}$ Meskipun secara langsung teks dalam perikop ini tidak berbicara tentang baptisan akan tetapi berkat Tuhan Yesus yang dideskripsikan dalam perikop ini serta kasih sayang Yesus yang luar biasa kepada anak-anak diprediksi hanya diperoleh oleh anak-anak melalui baptisan.

${ }^{35}$ Charles C. Ryrie, Teologi Dasar 2, (Yogyakarta: ANDI, 2010), hlm. 224-5.

${ }^{36}$ R. T. France, The Tyndale New Testament Commentaries: Matthew, (Surabaya: Momentum, 2007), p.283. Dalam tafsirannya terhadap perikop ini, France juga mengaitkannya dengan Matius 18:1-5.

${ }^{37}$ Ibid., p. 284.

${ }^{38}$ R. Alan Cole, The Tyndale New Testament Commentaries: Mark, (Surabaya: Momentum, 2007), p. 231.

${ }^{39}$ Ibid., p. 232.

${ }^{40}$ Jakob van Bruggen, Markus: Injil Menurut Petrus, (Jakarta: BPK Gunung Mulia,2006), hlm. 346. 
Jadi, sulit sekali untuk mengaitkan perikop ini secara langsung kepada praktik penyerahan anak - meskipun juga tidak bisa secara langsung dikaitkan dengan baptisan anak. Karena peristiwa ini hanya bersifat insidental saja.

Lukas 18:15-17. Menurut Matthew Henry untuk perikop ini, "Mereka membawa anakanaknya yang kecil kepada Yesus supaya Ia menjamah mereka sebagai tanda pemberian anugerah-Nya dan Roh-Nya ke atas mereka... Jika orangtua menjadi anggota dari jemaat yang ada di bumi ini, maka anak-anaknya juga termasuk sebagai anggota jemaat tersebut". ${ }^{41}$ Sedangkan bagi Leon Morris, "We must take touch them in the sense 'lay his hands on them', a natural action in blessing... The Master called the children and made them welcome. He went on to point out that it is the childlike to whom the kingdom of God belongs..". 42

Jadi, memang ketika orangtua (ayah) membawa anak-anak mereka kepada Yesus dengan tujuan supaya Yesus bisa memberkati mereka. Yesus pun menegaskan bahwa seseorang yang ingin masuk ke dalam Kerajaan Surga harus menjadi seperti anak kecil. Bahkan bagi Henry apabila orangtua sudah percaya kepada Yesus maka anak-anak mereka pun sudah dikategorikan sebagai orang yang percaya kepada Yesus. Hal itu terbukti dalam peristiwa ini di mana karena iman orangtua akhirnya anak-anak mereka pun dibawa kepada Yesus untuk menerima berkat. Tentu konsep ini sekali lagi bertentangan dengan anggapan kelompok yang kontra terhadap baptisan anak. Karena bagi mereka anak kecil belum bisa dikategorikan sebagai orang percaya sehingga jangan dulu dibaptis. Meskipun baptisan anak bukan sematamata berdasar kepada iman.

Lukas 2:21. Dalam ayat ini juga sama sekali tidak berbicara tentang penyerahan anak. Justru sebaliknya di sini berbicara tentang Yesus yang disunat pada hari kedelapan sesuai dengan Hukum Taurat. Meskipun dalam ayat 22 muncul frasa, “...untuk menyerahkan-Nya kepada Tuhan". Tetapi, apakah maksudnya frasa ini?'

Henry menegaskan, "Ini dilakukan dengan mata tertuju pada Hukum Taurat dan pada waktu yang ditetapkan oleh hukum Taurat, ketika umur-Nya empat puluh hari, ketika genap waktu pentahiran (ay.22)... yakni baik pentahiran sang ibu maupun sang anak, karena demikianlah yang dimaksudkan oleh hukum Taurat". ${ }^{43}$ Tentu hal ini kembali mengacu kepada Imamat 12. Di mana menjadi kewajiban bagi perempuan Israel yang selesai melahirkan untuk mentahirkan dirinya dan anak yang dilahirkan pada hari yang ke-40. Akan tetapi jikalau benar demikian, maka perikop ini pun tidak bisa dijadikan acuan untuk membenarkan praktik penyerahan anak dalam gereja. Mengapa? Pertama, karena sebelum masuk ke dalam tahap ini anak terlebih dahulu harus disunat. Artinya, untuk konteks sekarang anak harus dibaptis terlebih dahulu. Kedua, tentu tata cara atau pun substansi dari pada hari pentahiran ini dengan penyerahan anak sangat berbeda sehingga tidak dapat dikaitkan sama sekali.

Berdasarkan penjelasan beberapa ayat Alkitab yang selalu dijadikan dasar acuan bagi kelompok yang pro terhadap praktik penyerahan anak maka akan dicantumkan beberapa poin sebagai bahan evaluasi:

1. Dalam perikop Imamat 12 sama sekali tidak berbicara tentang pokok penyerahan anak. Justru yang lebih dominan di dalamnya adalah tentang sunat. Nah, bukankah sunat sudah digantikan baptisan dalam Perjanjian Baru. Karena sunat diberikan kepada anak-anak, maka tidak salah apabila baptisan pun dilayankan kepada mereka.

2. Matius 19:13-15; Markus 10:13-16; Lukas 18:15-17; memang berbicara tentang sekelompok ayah membawa anak-anak mereka kepada Yesus untuk menerima berkat. Akan tetapi dari beberapa tafsiran yang dijadikan sumber untuk melihat apa maksud

${ }^{41}$ Solomo Yo (Editor), Tafsiran Matthew Henry: Injil Lukas 13-24, (Surabaya: Momentum, 2009), hlm. 688-9.

${ }^{42}$ Leon Morris, The Tyndale New Testament Commentaries: Luke, (Surabaya: Momentum, 2006), p. 291.

${ }^{43}$ Solomo Yo (Editor), Tafsiran Matthew Henry: Injil Lukas 1-12, (Surabaya: Momentum, 2009), hlm. 93. 
perikop ini, ternyata ditemukan tidak ada satu pun yang membenarkan bahwa ayat ini berbicara tentang penyerahan anak. Meskipun ada informasi yang mengatakan bahwa memang sudah menjadi kebiasaan dalam budaya Israel untuk membawa anak-anak mereka kepada orang yang dianggap lebih tua dan memiliki kuasa serta hikmat guna memperoleh berkat. Akan tetapi, apakah dengan demikian perikop ini berbicara tentang penyerahan anak? Belum tentu, masih perlu dikaji lebih lanjut lagi. Satu hal yang cukup mencengangkan bahwa, rupanya perikop dalam Markus 10, dalam tradisi gereja justru dijadikan sumber untuk menguatkan baptisan anak, bukan penyerahan anak.

3. Dalam Lukas 2:21-22 juga tidak berbicara tentang penyerahan anak. Ada dua hal yang menjadi pokok di situ. Bahwa Yesus pada umur delapan hari disunat berdasarkan hukum Taurat. Kemudian pada umur 40 hari dia dibawa ke Bait Allah untuk mengikuti upacara pentahiran bersama dengan ibu-Nya, yakni Maria.

4. Berdasarkan riset yang sederhana ini, maka sebenarnya dalam baptisan anak sudah termuat elemen-elemen yang ada dalam penyerahan anak. Seperti, anak akan diberkati, anak akan menerima Roh Kudus, atau anak akan menerima janji berkat dari Allah Tritunggal. Akan tetapi dalam penyerahan anak, tidak termuat elemen-elemen yang substansi dari baptisan anak. Seperti, penyerahan anak tidak dapat disejajarkan dengan sunat dalam Perjanjian Lama bagi umat Israel. Padahal hal itu sangat penting dalam konteks umat Allah.

5. Dengan demikian, sebaiknya praktik penyerahan anak tidak lagi dilakukan oleh gereja, sebaliknya melakukan baptisan anak. Karena ajaran tentang baptisan anak lebih alkitabiah.

\section{E. Kesimpulan}

1. Alkitab dengan jelas mengajarkan tentang pokok baptisan anak. Oleh karena dalam Perjanjian Lama telah mengajarkan tentang sunat. Sedangkan sunat telah digantikan oleh baptisan dalam Perjanjian Baru. Kalau sunat dilakukakan kepada anak-anak, maka seharusnya baptisan pun juga demikian. Kemudian ada beberapa peristiwa dalam Alkitab yang mengindikasikan tentang ajaran baptisan anak. (Baca penjelasan dalam C.1.)

2. Istilah Bapto atau Baptizomai memang memiliki arti memandikan, mencelupkan, atau membasuh. Sehingga kuat indikasinya kepada baptis selam - secara tidak langsung menolak baptisan anak. Akan tetapi, dalam menerapkan cara ini, dapat dilakukan dengan berbagai macam cara. Bisa saja digunakan cara yang umum dipakai yakni, membawa benda ke dalam air lalu dicelupkan. Akan tetapi, bisa juga dengan cara air dibawa ke benda tersebut kemudian menyiram benda tersebut dengan air. Jikalau demikian, berarti baptisan anak juga dapat dibenarkan berdasarkan dua istilah di atas. Karena dilakukan dengan percik. (Baca penjelasan dalam C.2.)

3. Berdasarkan kesaksian dari Bapa-bapa Gereja menunjukkan bahwa dalam sejarah gereja perdana tidak terdapat larangan untuk membaptis seseorang berdasarkan umur. Justru sebaliknya, di mana menunjukkan bahwa dalam gereja perdana telah dipraktikkan baptisan dewasa dan juga baptisan anak. Bahkan nyaris tidak ada dari Bapa-bapa Gereja yang menyangkal atau mempertanyakan validitas baptisan anak. (Baca penjelasan dalam C.3.).

4. Berdasarkan makna dari baptisan, maka seharusnya memang anak-anak dibaptiskan. Seperti yang sudah dijelaskan di atas bahwa, baptisan anak sebagai lambang perjanjian anugerah, yang melaluinya anak-anak juga menerima anugerah di dalam Yesus Kristus. Baptisan anak juga dipahami sebagai alat anugerah bagi anak dan orangtua. Anak akan mengalami pertumbuhan spiritual secara progresif melalui baptisan. Di pihak lain, orangtua menjadi yakin akan janji-janji Allah akan diberikan 
dan dimiliki oleh anak-anaknya melalui baptisan. Terkahir, iman yang telah dimiliki oleh anak-anak akan mengalami pertumbuhan melalui baptisan.

5. Anak-anak dibaptis bukan karena alasan iman melainkan karena perjanjian. Hal yang sama diterapkan kepada sunat dalam Perjanjian Lama. Jadi, meskipun anak-anak belum menyadari akan iman mereka, akan tetapi karena mereka adalah jemaat Tuhan berdasarkan iman orangtua maka gereja wajib melayankan baptisan kepada mereka.

6. Gereja harus menyadari perbedaan antara baptisan anak dengan baptisan dewasa karena setelah pekabaran Injil. Sama halnya dalam Perjanjian Lama, ketika Tuhan baru saja mengikat perjanjian (covenan) dengan Abraham. Keturunan Abraham disunat pada waktu masih anak-anak, sedangkan Abraham pada waktu sudah tua.

7. Semua ayat yang kelompok pro terhadap penyerahan anak gunakan sebagai dasar untuk membenarkan konsep mereka kelihatan sangat dipaksakan.

8. Praktik penyerahan anak sebaiknya tidak lagi dilakukan oleh gereja. Oleh karena dalam baptisan anak sudah termuat semua elemen-elemen yang ada dalam penyerahan anak. Sebaliknya, dalam penyerahan anak tidak termuat elemen-elemen yang terdapat dalam baptisan anak.

\section{F. Literatur}

Berkhof, Louis,. Teologi Sistematika 5: Doktrin Gereja. Surabaya: Momentum, 2005.

Boice, James Montgomery,. Dasar-dasar Iman Kristen. Surabaya: Momentum, 2011.

Cole, R. Alan,. The Tyndale New Testament Commentaries: Mark. Surabaya: Momentum, 2007.

Erickson, Millard J.,. Teologi Kristen Volume Tiga. Malang: Gandum Mas, 2004.

France, R. T.,. The Tyndale New Testament Commentaries: Matthew. Surabaya: Momentum, 2007.

Grudem, Wayne,. Systematic Theology: An Introduction To Biblical Doctrine. Michigan, USA: Grand Rapids, 2011.

Hadiwijono, Harun,. Iman Kristen. Jakarta: BPK Gunung Mulia, 2005. (Cetakan ke-16)

Hall, David W., Peter A. Lillback (Editor). Penuntun Ke Dalam Teologi Intitutes Calvin. Surabaya: Momentum, 2009.

Johnson, Greg,. Article:Infant Baptism.

Kakiay, M. Ferry H.,. Teologi GBI. Jakarta: Kapernaum, 2003.

Morris, Leon,. The Tyndale New Testament Commentaries: Luke. Surabaya: Momentum, 2006.

Rayburn, Robert G.,. Apa Itu Baptisan?. Surabaya: Momentum, 2009.

Ryrie, Charles C.,. Teologi Dasar 2. Yogyakarta: ANDI, 2010.

van Bruggen, Jakob,. Markus: Injil Menurut Petrus. Jakarta: BPK Gunung Mulia, 2006.

Yo, Solomon, (Editor). Tafsiran Matthew Henry: Injil Lukas 1-12. Surabaya: Momentum, 2009.

Yo, Solomon, (Editor). Tafsiran Matthew Henry: Injil Lukas 13-24. Surabaya: Momentum, 2009.

Sproul, R. C.,. Kebenaran-Kebenaran Dasar Iman Kristen. Malang: SAAT, 2008

http://id.wikipedia.org/wiki/Gereja_Baptis/05/04/2013//

http://dbr.gbi-bogor.org/wiki/Penyerahan_anak/06/04/2013//

http//: ourunity.blogspot.com/2007/10/baptisan-bayi-sebuah-tinjauan.html/05/04/2013//

http://www.gbiwtcserpong.org/index.php/formulir-penyerahan-anak-2/27/04/2013//

http://dbr.gbi-bogor.org/wiki/Penyerahan_anak/06/04/2013// 